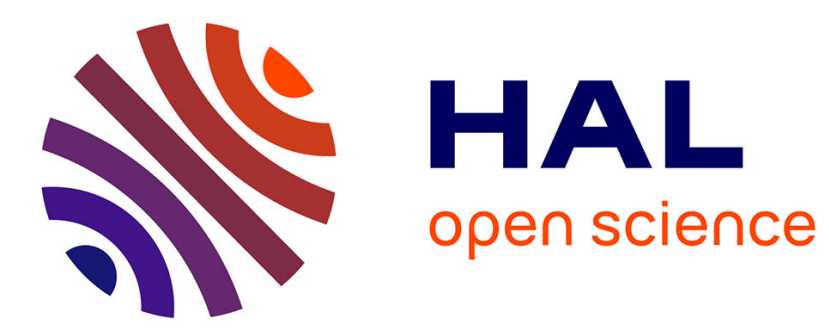

\title{
Recent Advances in the Understanding of Molecular Mechanisms of Resistance in Noctuid Pests
}

\author{
Gaëlle Le Goff, Ralf Nauen
}

\section{To cite this version:}

Gaëlle Le Goff, Ralf Nauen. Recent Advances in the Understanding of Molecular Mechanisms of Resistance in Noctuid Pests. Insects, 2021, 12 (8), 10.3390/insects12080674 . hal-03323818

\section{HAL Id: hal-03323818 \\ https://hal.inrae.fr/hal-03323818}

Submitted on 23 Aug 2021

HAL is a multi-disciplinary open access archive for the deposit and dissemination of scientific research documents, whether they are published or not. The documents may come from teaching and research institutions in France or abroad, or from public or private research centers.
L'archive ouverte pluridisciplinaire HAL, est destinée au dépôt et à la diffusion de documents scientifiques de niveau recherche, publiés ou non, émanant des établissements d'enseignement et de recherche français ou étrangers, des laboratoires publics ou privés. 


\title{
Recent Advances in the Understanding of Molecular Mechanisms of Resistance in Noctuid Pests
}

\author{
Gaëlle Le Goff ${ }^{1, *(D)}$ and Ralf Nauen ${ }^{2, *(D)}$ \\ 1 Université Côte d'Azur, INRAE, CNRS, ISA, F-06903 Sophia Antipolis, France \\ 2 Bayer AG, Crop Science Division, R\&D Pest Control, Alfred Nobel Str. 50, 40789 Monheim, Germany \\ * Correspondence: gaelle.le-goff@inrae.fr (G.L.G.); ralf.nauen@bayer.com (R.N.); Tel.: +33-4-9238-6578 (G.L.G.); \\ +49-21-7338-4441 (R.N.)
}

check for updates

Citation: Le Goff, G.; Nauen, R. Recent Advances in the

Understanding of Molecular Mechanisms of Resistance in Noctuid Pests. Insects 2021, 12, 674. https:// doi.org/10.3390/insects12080674

Received: 16 July 2021

Accepted: 24 July 2021

Published: 27 July 2021

Publisher's Note: MDPI stays neutral with regard to jurisdictional claims in published maps and institutional affiliations.

Copyright: (c) 2021 by the authors. Licensee MDPI, Basel, Switzerland. This article is an open access article distributed under the terms and conditions of the Creative Commons Attribution (CC BY) license (https:// creativecommons.org/licenses/by/ $4.0 /$ )
Noctuid moths are among the most devastating crop pests on the planet. Many of them are polyphagous pests capable of feeding on numerous host plants. Their larval stages cause significant damage to plants of agronomic importance, including corn, cotton, soybean, and rice, which result in severe yield losses if not kept under economic damage thresholds. Control of these pest insects is mainly based on the use of chemical insecticides and/or the cultivation of transgenic plants expressing Bacillus thuringiensis (Bt) poreforming insecticidal proteins (Cry toxins). However, the efficacy of these control measures is often jeopardized by the development of resistance due to frequent applications of insecticides and long-term exposure to a relatively small set of Cry toxins expressed in transgenic crops. Understanding the molecular mechanisms of resistance that these pest insects have developed is essential for the implementation of sustainable control methods and resistance management strategies. This special issue is dedicated to this topic and includes 10 papers presenting either original results or reviews.

Several species of the noctuid moth family are invasive species that have recently spread to various parts of the world. The most problematic is probably Spodoptera frugiperda (Smith, 1797), which originated from the American continent and recently invaded the Western hemisphere. It was first detected in Africa in 2016 and later in Asia (2018) and Australia (2020). It is approaching Europe and was detected in the Canary Islands (Spain) in July 2020. The Food and Agriculture Organization (FAO) has this year proclaimed it as "one of the most destructive pests jeopardizing food security across vast regions of the globe". The importance of this species, also known as the fall armyworm (FAW), is reflected in the Special Issue, with half of the publications dedicated to it. Some of the papers focus on the diagnosis to differentiate the two sympatric host plant species of FAW, maize and rice [1], or on the most suitable rearing conditions for this non-model species [2], while others tackle the development of molecular tools for the detection of mutations in insecticide targets conferring resistance [3]. Other studies have monitored the presence of known mutations in the targets of major insecticide classes by comparing native and invasive populations [1,4]. Marked differences exist between FAW populations, which can provide guidance for appropriate resistance management decisions. Indeed, these studies show the presence of mutations in acetylcholinesterase, the target of carbamates and organophosphates, in both native and invasive populations, whereas only native populations show a deletion in ABCC2, the target of some Bt proteins [1,4]. In this case, diamide insecticides could be useful in the fight against FAW since none of the known mutations in the target of diamides, the ryanodine receptor, have been detected. However, it should not be forgotten that resistance can also be acquired through increased capacity to metabolize insecticides and involves detoxification enzymes, such as cytochromes P450 monooxygenases, carboxylesterases, glutathione S-transferases, or transporters like ATP binding cassette $(\mathrm{ABC})$ transporters. Some of the roles of these detoxification genes are highlighted in a review on species in the genus Spodoptera [5]. Nevertheless, the fight against insect pests must also include research and discovery of new molecules with 
different modes of action to counteract resistance mechanisms. Such research should also take into account a societal demand for the development of more environmentally friendly molecules [6].

The other noctuid moth species covered in this Special Issue are also important pests. Klai et al. proposed an analysis of the presence of transposable elements in the genome of Helicoverpa armigera and focused on their presence in detoxification genes as they may cause changes in the expression level and confer resistance [7]. Other authors have sought to develop molecular tools either to differentiate between two closely related species, such as Mythimna loreyi and Mythimna separata, with the LAMP (loop-mediated isothermal amplification) assay [8], or by designing primers to monitor the expression of Bt toxin target genes and reference genes in soybean looper, Chrysodeixis includens [9].

$\mathrm{ABC}$ transporters are important Bt protein receptors and there is an increasing body of evidence that mutations in $\mathrm{ABC}$ transporters (e.g., $\mathrm{ABCC}$ ) confer high levels of resistance to Cry toxins as reviewed in [10]. In his review, Heckel [10] highlights a number of research questions that remain open, such as how potential Cry toxin receptor proteins and Cry toxins interact to form pores. However, our knowledge and understanding regarding the function and regulation of genes conferring resistance in pests is constantly increasing and particularly facilitated by the exploitation of new technologies, such as genome editing by CRISPR/Cas9.

Finally, we would like to thank all authors for their commitment to contribute their articles and the many reviewers for their valuable comments and suggestions helping all of us to shape this interesting Special Issue, which hopefully attracts a broad readership of Insects.

Institutional Review Board Statement: Not applicable.

Informed Consent Statement: Not applicable.

Data Availability Statement: Not applicable.

Conflicts of Interest: The authors declare no conflict of interest.

\section{References}

1. Boaventura, D.; Martin, M.; Pozzebon, A.; Mota-Sanchez, D.; Nauen, R. Monitoring of Target-Site Mutations Conferring Insecticide Resistance in Spodoptera frugiperda. Insects 2020, 11, 545. [CrossRef] [PubMed]

2. Gergs, A.; Baden, C. A Dynamic Energy Budget Approach for the Prediction of Development Times and Variability in Spodoptera frugiperda Rearing. Insects 2021, 12, 300. [CrossRef] [PubMed]

3. Schlum, K.; Lamour, K.; Tandy, P.; Emrich, S.; de Bortoli, C.; Rao, T.; Dillon, D.V.; Linares-Ramirez, A.; Jurat-Fuentes, J. Genetic Screening to Identify Candidate Resistance Alleles to Cry1F Corn in Fall Armyworm Using Targeted Sequencing. Insects 2021, 12, 618. [CrossRef]

4. Yainna, S.; Nègre, N.; Silvie, P.; Brévault, T.; Tay, W.; Gordon, K.; Dalençon, E.; Walsh, T.; Nam, K. Geographic Monitoring of Insecticide Resistance Mutations in Native and Invasive Populations of the Fall Armyworm. Insects 2021, 12, 468. [CrossRef] [PubMed]

5. Hilliou, F.; Chertemps, T.; Maïbèche, M.; Le Goff, G. Resistance in the Genus Spodoptera: Key Insect Detoxification Genes. Insects 2021, 12, 544. [CrossRef] [PubMed]

6. Ruttanaphan, T.; De Sousa, G.; Pengsook, A.; Pluempanupat, W.; Huditz, H.-I.; Bullangpoti, V.; Le Goff, G. A Novel Insecticidal Molecule Extracted from Alpinia galanga with Potential to Control the Pest Insect Spodoptera frugiperda. Insects 2020, 11, 686. [CrossRef] [PubMed]

7. Klai, K.; Chénais, B.; Zidi, M.; Djebbi, S.; Caruso, A.; Denis, F.; Confais, J.; Badawi, M.; Casse, N.; Khemakhem, M.M. Screening of Helicoverpa armigera Mobilome Revealed Transposable Element Insertions in Insecticide Resistance Genes. Insects 2020, 11, 879. [CrossRef] [PubMed]

8. Nam, H.Y.; Kwon, M.; Kim, H.J.; Kim, J. Development of a Species Diagnostic Molecular Tool for an Invasive Pest, Mythimna loreyi, Using LAMP. Insects 2020, 11, 817. [CrossRef] [PubMed]

9. Martin, M.; Boaventura, D.; Nauen, R. Evaluation of Reference Genes and Expression Level of Genes Potentially Involved in the Mode of Action of Cry1Ac and Cry1F in a Susceptible Reference Strain of Chrysodeixis includens. Insects 2021, 12, 598. [CrossRef] [PubMed]

10. Heckel, D. The Essential and Enigmatic Role of ABC Transporters in Bt Resistance of Noctuids and Other Insect Pests of Agriculture. Insects 2021, 12, 389. [CrossRef] [PubMed] 